\section{IJ§ER}

ISSN: 2149-5939
International Journal of Social Sciences and Education Research

Online, http://dergipark.gov.tr/ijsser

Volume: 2(3), 2016

\title{
The analysis of accounting and taxable profit: Evidence from firms indexed on MBI10
}

\author{
Rufi Osmani ${ }^{1} \quad$ Fitim Deari ${ }^{2}$
}

Received Date: 02 / 09 /2016 Accepted Date: 30 / 09 / 2016

\begin{abstract}
The purpose of this study is to examine the accounting versus taxable profit for selected firms. Totally nine firms are examined for the period 2010-2014. Selected firms are indexed on Macedonian Stock Exchange Index - MBI10 and belong to different industry sectors. Selected firms are the most liquid on Macedonian Stock Exchange, have better business performance and financial statements are prepared in accordance with IAS and IFRS. The analysis is focused on effects of additional fiscal costs (firm income tax) to net profit (loss). The analysis argues that despite the fact that formally Macedonia ranks among the countries with lower fiscal burden of $10 \%$ tax (personal income tax and profit tax), the level of real fiscal cost is much higher and very asymmetric. This additional fiscal cost and this fiscal asymmetry is the result of the fact that the law on profit tax in whole or part taxed in additional way 25 types of operating expenses which are considered irrelevant; and even these costs exceed the minimum limits set by the government of the country. In the case of Macedonia, fiscal provisions of the law on profit tax affect illogically situations that even firms operate with loss they should pay income tax; and consequently, this increase the business loss on one hand and decrease the economic and financial performance on the other hand.
\end{abstract}

Keywords: Accounting Profit, Taxable Profit, Financial Performance, Listed Firms

\section{Introduction}

Accounting system as an information system has own characteristics not just view from the firm perspective, but also from the country perspective. As an information system, the traditional role of accounting is to provide information for the entity's stakeholders. Managers, shareholders, investors, creditors, government, etc. are interested on a particular entity. But, understanding accounting information sometimes becomes not an easy task for users, especially for firms abroad. Even to, financial statements are prepared in accordance with Generally Accepted Accounting Principles (GAAP), yet there are difficulties in reading the accounting information. Differences and difficulties should be prior known by investors, creditors and others which planning to make decisions.

Information users should know not just the accounting system, but the environment in which that systems works. Legal, economic, financial, cultural etc. environments are important to be examined during reading accounting information. They affect accounting policies, and hence the way how information is prepared and reported. Namely, in this paper we try to present differences

\footnotetext{
${ }^{1}$ Associate Professor, PhD, Faculty of Business and Economics, South East European University, 1200 Tetovo, Republic of Macedonia, E-mail: rufi.osmani@seeu.edu.mk

${ }^{2}$ The correspondent author, Assistant Professor, PhD, Faculty of Business and Economics, South East European University, 1200 Tetovo, Republic of Macedonia, E-mail: f.deari@seeu.edu.mk
} 
Osmani, R, Deari, F. (2016). The analysis of accounting and taxable profit: Evidence from firms indexed on MBI10. International Journal of Social Sciences and Education Research, 2 (3), 991-999.

between Income statement and Tax statement. More precisely, we try to examine differences between accounting vs. taxable profit in the case of the Republic of Macedonia.

Macedonia experienced highest level of unemployment and poverty in Europe due to the low level of foreign direct investment, the lack of national investment, the hesitation of the banking sector in financing new investments as a result of the growth of bad loans and considerable reduction of economic remittances (Osmani, 2016).

Macedonia's government authorities with purpose to create an attractive business environment, to reduce higher unemployment and poverty rate and attract Foreign Direct Investments (hereafter FDI), did essential reforms of the national fiscal system. Emphasized reform was profit and personal income tax rate of $10 \%$, ranking hence Macedonia as the country with the lower rate comparing with European countries.

The country fiscal perspective predicts that in cases when firms decide to reinvest profit and not to pay dividend for shareholders, profit tax rate will be zero, except the additional fiscal burden that is study object of this paper.

Low income tax rate even to is enough favorable for investors, generally it is deformed by Law on profit tax and considerable creates additional fiscal cost giving hence priority to the concept "fiscal or taxable profit" in damages of the concept "accounting profit".

According to the Tax statement (for more see "Danocen bilans za odanocuvanje na dobivka", Sluzben vesnik na RM, br. 174/14, Skopje, 2015) that is a mandatory report for all economic and uneconomic entities and that is derived from the Law on profit tax, there are 25 types of operating expenses which partially or entirely taxed with tax on profit and partly with personal income tax. This fact disables finding the exact level of the real or effective rate of fiscal cost for firms depending on the type and level of operating expenses, which incurred in their operating activities.

As a result of serious conceptual differences between "accounting profit" and "taxable profit" in the case of analyzed firms in this study paradoxical cases are appeared. Firms although don't pay dividends but reinvest profits; they must pay profit and income tax. Moreover, in other cases firms calculate and pay profit (loss) tax which direct worsens their economic and financial performances.

As a consequence of the above findings, results from selected firms put on light very asymmetrical real tax on profit and arguing hence the need for revision of provisions of the law in question in terms of greater harmonization of the concept of "taxable profit" with "accounting profit". Moreover, this harmonization should be in line with IAS/ IFRS and good practices of transition countries that have successfully implemented structural reforms and have attracted more FDI.

The rest of this paper is organized as following: Section 2 presents literature review and definition of the problem. Section 3 presents the research methodology. Section 4 presents results and discussion. Finally, section 5 presents some conclusions/recommendations followed then by references/bibliography.

\section{Literature review and definition of the problem}

There are several studies on the topic of accounting profit versus taxable profit. The respectively debate is ongoing, and some selected studies are presented as following. 
Osmani, R, Deari, F. (2016). The analysis of accounting and taxable profit: Evidence from firms indexed on MBI10. International Journal of Social Sciences and Education Research, 2 (3), 991-999.

Carlon, Tran and Tran-Nam (2012) have examined historical data of 21 large Australia companies for the period 2005 to 2010 to estimate the effective tax rates. Their study revealed that taxable profit was enough close to accounting profit and hence respectively rates were quite close to each other.

Desai (2003) has examined the difference between book income and tax income emphasized hence the differential treatments of depreciation, the reporting of foreign source income, and the changing nature of employee compensation.

"While there is little debate that the incomes are diverging, what is causing the divergence and whether and how to fix it are very much open questions." (Hanlon and Shevlin, 2005, p. 126) Furthermore, authors explain how book and taxable income are calculated and explain differences between them. For example, authors mentioned municipal bond interest which is a part of income according to financial accounting, but not of taxable income. Moreover, authors explained depreciation expense as a temporary difference, bad debt expense, etc. Authors summarized that "financial accounting income is intended to provide information regarding firm performance to the marketplace, while taxable income is prescribed by the government to meet budgetary needs and to provide incentives (disincentives) for desired (undesired) behavior" (Hanlon and Shevlin, 2005, p. 106).

In this study we follow Hanlon and Shevlin (2005) for the case of listed and selected firms. The difference between accounting and taxable profit is known in fiscal and financial accounting literature. But, no previous research is performed for this issue in case of firms in Macedonia. Therefore, we believe that this will be a pioneer study and will be advanced in future by ourselves and other authors.

Before we start with data and methodology, definition of the problem (accounting vs. taxable profit) is needed. Also, a cross-section discussion between respectively definitions and specifics of legal aspects in case of Macedonia are welcomed too.

Definition of accounting profit is whole in accordance with the accountancy law (for more see “Zakon za smetkovodstvo", SV na RM, br. 95/2012) in Macedonia and is reported on income statement. But, there is essential difference between the concept "taxable profit" defined by IAS and IFRS and international fiscal standards and "fiscal profit" defined by the tax law (for more see "Zakon za danok od dobivka na RM", SV. 13/2014) in Macedonia.

Law on profit tax prescribes that calculated accounting profit on income statement to be increased with 25 types of operating expenses. Operating expenses which increase fiscal profit base can be regroup in some categories:

(1) Compensations to employee more than the minimum level determined by social conventions approved by the partnership tripartite (Government, Chamber of Commerce and Syndicate).

(2) Extraordinary expenses that incur in situations of business disputes that require judicial epilogue.

(3) Expenses from relationships among the firms that have business connection functionality and ownership.

(4) Expenses that cannot be listed in the framework of the above three types. 
Osmani, R, Deari, F. (2016). The analysis of accounting and taxable profit: Evidence from firms indexed on MBI10. International Journal of Social Sciences and Education Research, 2 (3), 991-999.

In the case of expenses taxation listed in the first group, if they exceed the minimum level defined by social conventions not only taxed at $10 \%$ tax on profit but also taxed at $10 \%$ personal tax. This addition tax is addressed or the firm as economic entity or employee and effectuates additional fiscal cost to income of $20 \%$.

In the case of expenses taxation listed in the second group, firms from of litigation are presented additional expenses without the guarantee that judicial Decision making will be correct. At the same time in most cases the debtors do not pay the debt and additional costs due to not functioning of the legal system and the extreme politicization of the public administration in general. This observation is accompanied by more cases where debtors have blocked bank accounts and is subject to bankruptcy process conform bankruptcy law, despite the fact that the creditor wins dispute, debtors don't have mass bankruptcy and liquid assets to pay debts.

In the case of the expenses listed in the third group, exists fiscal reasonability that these expenses to be taxed if they are above the level defined by legal standards or above the market cost because it comes to firms that have joint shareholders ownership.

In the case of the expenses listed in the fourth group, it appears the phenomenon that the state discriminates the private sector to the benefit of the public sector for investments made into new human resources, in donations in the function of protection of living environment and in some types of operating expenses in addition to taxation with additional profit tax does not disburse the VAT in these types of expenses. Within the benefits and facilities of the law on profit tax (for more see "Zakon za danok od dobivka na RM", SV. 13/2014, paragraph 9) is foreseen for the firms to decrease the profit tax base on behalf of the operating expenses which are prior calculated and have produced positive results in terms of collection of accounts receivable with judicial dispute.

\section{Research methodology}

Performed analysis covers nine firms from Macedonian Stock Exchange (hereafter MSE) for the period 2010-2014. Selected firms are the most liquid firms and are permanently listed on MSE and also MBI10.

Data used in this study are primary data extracted from firms' annual reports published on $\mathrm{http} / / / \mathrm{www} . \mathrm{mse} . \mathrm{mk} / \mathrm{mk} /$. Data are expressed on thousands denars ('000 denars) and are on annual level.

Selected firms are as below:

- Makpetrol Skopje (MPT),

- $\quad$ Alkaloid Skopje (ALK),

- Granit Skopje (GRNT),

- Cementarnica USJE AD Skopje (USJE),

- $\quad$ Ading AD Skopje (ADIN),

- Stopanska banka AD Skopje (STB),

- $\quad$ NLB Banka AD Skopje (TNB), 
Osmani, R, Deari, F. (2016). The analysis of accounting and taxable profit: Evidence from firms indexed on MBI10. International Journal of Social Sciences and Education Research, 2 (3), 991-999.

- $\quad$ Komercijalna banka AD Skopje (KMB) and

- $\quad$ Ohridska banka AD Skopje (OHB).

Taxable profit is calculated in Tax statement increased hence accounting profit for 25 types of operating expenses which are clearly numbered. We try to integrate in this paper data from accounting and taxable profit, and profit tax level which is paid from firms within a weighted average for purpose to analyze respectively trends.

Results from weighted averages have own limitations due to enough asymmetric data. These asymmetries come from different policies of dividend allocations, different levels of operative expenses which are taxed and are dependent directly from firm's activity, position in market and other factors not known by authors in this study.

\section{Results and discussion}

In this section are presented obtained results associated with respectively comments. Each selected firm is examined as the independent case study. With other words, results are specific per each examined firm. Obtained results cannot be generalized, but findings from all examined firms we are trying to put on light what is the common and relevant.

\subsection{Makpetrol Skopje}

Makpetrol Skopje is the most emphasized case in which is evidenced large discrepancy between accounting and taxable profit as presented on table 1 .

Table 1. Makpetrol Skopje, MPT

\begin{tabular}{|c|c|c|c|c|c|}
\hline Description & 2010 & 2011 & 2012 & 2013 & 2014 \\
\hline Profit (loss) before tax & $-218,268$ & 5,769 & $-56,312$ & $-217,900$ & $-123,586$ \\
\hline Income tax expense (10\%) & $/$ & 577 & $/$ & $/$ & $/$ \\
\hline Profit (loss) for the year & $-218,268$ & 5,192 & $-56,312$ & $-217,900$ & $-123,586$ \\
\hline Income tax expense & 13,219 & 8,778 & 10,155 & 9,022 & 669 \\
\hline Real income tax rate, \% & $6.06 \%$ & $152.16 \%$ & $18.03 \%$ & $4.14 \%$ & $0.54 \%$ \\
\hline Profit (loss) for the year & $-233,150$ & $-3,009$ & $-67,391$ & $-226,922$ & $-124,255$ \\
\hline
\end{tabular}

Source: Annual reports and authors own calculations.

Makpetrol Skopje is one of the largest firms in the country. Makpetrol Skopje for the period 2010-2014 has very asymmetric trends having in consideration that except 2011, in all rest years has operated with loss. Despite fact the firm has loss, it has to pay profit (loss) tax liability and hence has additional fiscal burden which worse its economic and financial performance. Thus, effective profit tax rate in 2010 is $6 \%$, in 2012 is $18 \%$, in 2013 is $4 \%$ and in 2014 is $0.5 \%$.

In analyzed years $(2010,2012,2013$ and 2014) in fact the firm has to pay tax on loss and thus increased loss for 33,065,000 denars. Furthermore, in 2011 the firm has profit of 5,192,000 denars and has to pay profit tax of $8,778,000$ denars or with the effective rate of $152.16 \%$. The firm closes 2011 with a net loss of 3,009,000 denars. Respectively average ratios in the case of MPT are not calculated as in rest selected firms due to above asymmetries. 
Osmani, R, Deari, F. (2016). The analysis of accounting and taxable profit: Evidence from firms indexed on MBI10. International Journal of Social Sciences and Education Research, 2 (3), 991-999.

\subsection{Alkaloid Skopje}

Alkaloid Skopje is the case which manifests different trends and levels comparing with MPT for the period 2010-2014 despite the fact that both operate within same country economy and are subject of same legal and fiscal provisions.

Table 2. Alkaloid Skopje, ALK

\begin{tabular}{|c|c|c|c|c|c|c|}
\hline Description & 2010 & 2011 & 2012 & 2013 & 2014 & Average \\
\hline Profit (loss) before tax & 628,718 & 662,195 & 640,041 & 671,283 & 746,046 & 669,657 \\
\hline Income tax expense (10\%) & 62,872 & 66,220 & 64,004 & 67,128 & 74,605 & 66,966 \\
\hline Profit (loss) for the year & 565,846 & 595,976 & 576,037 & 604,155 & 671,441 & 602,691 \\
\hline Income tax expense & 54,379 & 45,942 & 56,311 & 70,857 & 127,592 & 71,016 \\
\hline Real income tax rate, $\%$ & $8.65 \%$ & $6.94 \%$ & $8.80 \%$ & $10.56 \%$ & $17.10 \%$ & $10.41 \%$ \\
\hline Profit (loss) for the year & 574,339 & 616,253 & 583,730 & 600,426 & 618,454 & 598,640 \\
\hline
\end{tabular}

Source: Annual reports and authors own calculations.

The low level of profit tax comparing with compulsory rate $10 \%$ is result of the fact that the firm do profit reinvestment and don't pay dividends or pay in low level. In 2014 when the firm has paid dividends, profit tax rate is $17.10 \%$ as a result of operative expenses taxation legislated on Tax statement.

The effective average profit tax rate in case of the ALK for the analyzed period is $10.41 \%$, which makes a wrong perception that additional fiscal burden is just $0.41 \%$. Of course, a better explanation could be given if Tax statement data were publicly available.

\subsection{Granit Skopje}

The analyzing historical data of GRANIT brings on light taxation trends and levels different from previous firms. On average GRNT has the effective profit tax rate of $5.94 \%$ for the period 2010-2014. Except 2013 and 2014 when the firm has paid dividends and consequently profit tax rate is $14.92 \%$ respectively $12.55 \%$, in rest years are evidenced enough lower rates as $1.39 \%$, $0.46 \%$ and $0.38 \%$.

Table 3. Granit Skopje, GRANIT

\begin{tabular}{|c|c|c|c|c|c|c|}
\hline Description & 2010 & 2011 & 2012 & 2013 & 2014 & Average \\
\hline Profit (loss) before tax & 288,455 & 382,323 & 325,879 & 423,567 & 215,153 & 327,075 \\
\hline Income tax expense 10\%) & 28,846 & 38,232 & 32,588 & 42,357 & 21,515 & 32,708 \\
\hline Profit (loss) for the year & 259,610 & 344,091 & 293,291 & 381,210 & 193,638 & 294,368 \\
\hline Income tax expense & 4,023 & 1,772 & 1,237 & 63,208 & 26,993 & 19,447 \\
\hline Real income tax rate, $\%$ & $1.39 \%$ & $0.46 \%$ & $0.38 \%$ & $14.92 \%$ & $12.55 \%$ & $5.94 \%$ \\
\hline Profit (loss) for the year & 284,432 & 380,551 & 324,642 & 360,359 & 188,160 & 307,629 \\
\hline
\end{tabular}

Source: Annual reports and authors own calculations.

\subsection{Cementarnica USJE AD Skopje}

The case of USJE is slightly similar with GRNT. Differences between these two firms are as result of the company economic activity, structure and other level of operative expenses, rational managing of taxable expenses and reinvesting profit that hence has affected an average 3,67\% effective profit tax rate. 
Osmani, R, Deari, F. (2016). The analysis of accounting and taxable profit: Evidence from firms indexed on MBI10. International Journal of Social Sciences and Education Research, 2 (3), 991-999.

Table 4. Cementarnica USJE AD Skopje, USJE

\begin{tabular}{|c|c|c|c|c|c|c|}
\hline Description & 2010 & 2011 & 2012 & 2013 & 2014 & Average \\
\hline Profit (loss) before tax & $1,619,234$ & $1,927,887$ & $1,321,248$ & $1,494,372$ & $1,628,071$ & $1,598,162$ \\
\hline Income tax expense (10\%) & 161,923 & 192,789 & 132,125 & 149,437 & 162,807 & 159,816 \\
\hline Profit (loss) for the year & $1,457,311$ & $1,735,098$ & $1,189,123$ & $1,344,935$ & $1,465,264$ & $1,438,346$ \\
\hline Income tax expense & 113,929 & 9,432 & 3,470 & 4,530 & 167,332 & 59,739 \\
\hline Real income tax rate, $\%$ & $7.04 \%$ & $0.49 \%$ & $0.26 \%$ & $0.30 \%$ & $10.28 \%$ & $3.67 \%$ \\
\hline Profit (loss) for the year & $1,505,242$ & $1,918,442$ & $1,317,778$ & $1,489,842$ & $1,460,739$ & $1,538,409$ \\
\hline
\end{tabular}

Source: Annual reports and authors own calculations.

This average profit tax rate of 3,67\% for the period 2010-2014 is addressed additional profit tax and personal tax of operative expenses mainly first and second type of expenses and don't address real profit tax as a result of restrictive policies of dividends allocation, respectively firm's profit reinvestment.

\subsection{Ading}

Data analysis for firm "Ading" for the period 2010-2014 puts on light similar trends and comparatively differences with other analyzed firms in this study. In 2014 despite the fact the firm has reported loss before tax in amount of 1,817,000 denars, the firm must calculate profit tax of $2,433,000$ denars and thus has a very high rate of $134 \%$.

Table 5. Ading AD Skopje, ADIN

\begin{tabular}{|c|c|c|c|c|c|c|}
\hline Description & 2010 & 2011 & 2012 & 2013 & 2014 & Average \\
\hline Profit (loss) before tax & 8,391 & 29,994 & 7,950 & 13,920 & $-1,817$ & 11,688 \\
\hline Income tax expense (10\%) & 839 & 2,999 & 795 & 1,392 & $/$ & 1,506 \\
\hline Profit (loss) for the year & 7,552 & 26,995 & 7,155 & 12,528 & $-1,817$ & 10,483 \\
\hline Income tax expense & 521 & 708 & 479 & 1,010 & 2,433 & 1,030 \\
\hline Real income tax rate, \% & $6.21 \%$ & $2.36 \%$ & $6.03 \%$ & $7.26 \%$ & $133.90 \%$ & $31.15 \%$ \\
\hline Profit (loss) for the year & 7,870 & 29,286 & 7,471 & 10,324 & $-2,082$ & 10,574 \\
\hline
\end{tabular}

Source: Annual reports and authors own calculations.

In 2014, despite this higher calculated profit tax, the firm increased loss just for 265,000 denars, respectively total evidenced loss is just 2,082,000 denars. In this case is presented phenomena of profit tax decreasing in amount of 2,168,000 $(1,817,000+2,433,000-2,082,000)$ denars in name of so called tax credit (tax deduction) according to operative expenses of second level based on writes-off of bad debt (accounts receivable) from previous period.

Average profit tax rate of $31,15 \%$ is as a result of enough high level of profit tax rate $134 \%$ in year 2014 and argument high discrepancy between accounting and tax profit on one hand and on another hand the country's fiscal policies unsuitability.

4.6. NLB Banka AD Skopje, Stopanska banka AD Skopje, Komercijalna banka AD Skopje and Ohridska banka AD Skopje

Banking sector analysis via selected and more representative banks in country, and listing on same time within more liquid firms in Skopje Stock Exchange proves that average effective profit rate is $4,53 \%$. This rate is very low comparing with formal rate of $10 \%$.

Separately analyzes according banks of the profit tax rate for selected period 2010-2014 on average has evidenced following trends: Stopanska banka AD Skopje (2,96\%), NLB Banka AD 
Osmani, R, Deari, F. (2016). The analysis of accounting and taxable profit: Evidence from firms indexed on MBI10. International Journal of Social Sciences and Education Research, 2 (3), 991-999.

Skopje (2,62\%), Komercijalna banka AD Skopje (5,04\%) and Ohridska banka AD Skopje $(7,48 \%)$.

Table 6. TNB, STB, KMB and OHB

\begin{tabular}{|c|c|c|c|c|c|}
\hline \multirow{2}{*}{ Description } & $2010-2014$ & $2010-2014$ & $2010-2014$ & $2010-2014$ & $2010-2014$ \\
\cline { 2 - 6 } & STP & NLB & KMB & OHB & Average \\
\hline Profit (loss) before tax & $1,002,602$ & 603,794 & 660,146 & 124,132 & 597,669 \\
\hline Income tax expense (10\%) & 100,260 & 60,379 & 66,015 & 12,413 & 59,767 \\
\hline Profit (loss) for the year & 902,342 & 543,415 & 594,131 & 111,719 & 537,902 \\
\hline Income tax expense & 41,850 & 18,707 & 8,385 & 8,939 & 19,470 \\
\hline Real income tax rate, \% & $2.96 \%$ & $2.62 \%$ & $5.04 \%$ & $7.48 \%$ & $4.53 \%$ \\
\hline Profit (loss) for the year & 960,752 & 584,712 & 651,761 & 115,193 & 578,105 \\
\hline
\end{tabular}

Source: Annual reports and authors own calculations.

Figure 1. Real vs. official income tax

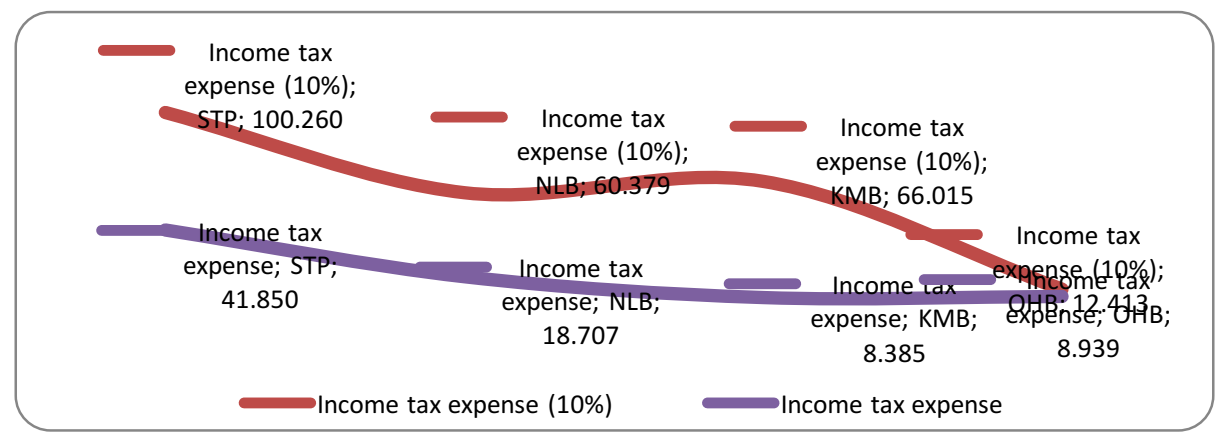

Source: Annual reports and authors own calculations.

The average effective profit tax rate of $4,53 \%$ in case of commercial banks is addressed to taxation of whole operative expenses and is sequence of profit reinvestment; and not dividend payment which in legal aspect don't affect obligation of profit tax calculation and payment.

\section{Conclusions and recommendations}

The purpose of this study was to analyze the real or effective profit tax rate of the most liquid firms listed on Macedonian Stock Exchange. For the selected period 2010-2014 results denoted that there is a large asymmetry between level and size of profit tax which is calculated and paid by selected firms.

This asymmetry is as consequence of the fact that firms report different levels of accounting profit, while the state forced to pay tax on profit based on taxable profit, concept this enough specific and discriminate in case of Macedonia.

According to profit tax law, accounting profit should be increased for 25 types of operative expenses. But, in this study was evidenced that at some firms loss is taxable and have been applied high profit tax rates during dividends allocation comparing with official rate of $10 \%$. Other firms that used legal beneficiaries and reinvested profit, paid profit tax just on level of operative expenses and hence the profit tax rate was lower than the formal rate of $10 \%$.

We recommend that this significant and asymmetric gap between rate and level of profit tax should be avoided via harmonization (adjusting) the concept "taxable profit" (Law on profit tax) 
Osmani, R, Deari, F. (2016). The analysis of accounting and taxable profit: Evidence from firms indexed on MBI10. International Journal of Social Sciences and Education Research, 2 (3), 991-999.

in accordance with concept of "accounting profit" (IAS and IFRS). Thus, additional taxation of operative expenses will be eliminated.

Furthermore, we recommend that fiscal reforms of income tax should replace so called "flat tax" with concept "progressive tax". Finally, we recommend changes of fiscal laws in the country for more transparency of fiscal reports (statements) for further more detailed scientific studies, which in same time present limitations in this study too.

\section{References}

Carlon, S., Tran, A., Tran-Nam, B. (2012). How Close Are Taxable Income and Accounting Profit? An Empirical Study of Large Australian Companies. Retrieved from: http://docs.business.auckland.ac.nz/Doc/12-Shirley-Carlon-Alfred-Tran-Binh-Tran-Nam.pdf [accessed on June 26, 2016]

Danocen bilans za odanocuvanje na dobivka, Sluzben vesnik na RM, br. 174/14, Skopje, 2015.

Desai, A. M. (2003). The Divergence between Book Income and Tax Income, Tax Policy and the Economy, Volume 17, MIT Press. Retrieved from: http://www.nber.org/chapters/c11538.pdf [accessed on June 26, 2016]

Hanlon, M. Shevlin, T. (2005). Book-Tax Conformity for Corporate Income: An Introduction to the Issues, Tax Policy and the Economy, Volume 19, MIT Press. Retrieved from: http://www.nber.org/chapters/c0166.pdf [accessed on June 26, 2016]

Macedonian Stock Exchange, http://www.mse.mk/mk/

Osmani, R. (2016). Improved Business Climate and FDI in the Western Balkans. Journal of Economic and Social Studies, 6 (1). ISSN 1986 - 8502, doi: http://dx.doi.org/10.14706/JECOSS16611 (In Press)

Zakon za danok od dobivka na RM, SV. 13/2014

Zakon za smetkovodstvo, SV na RM, br. 95/2012 